U.S. DEPARTMENT OF THE INTERIOR

U.S. GEOLOGICAL SURVEY

\title{
Preliminary Investigation of Structural Controls of Ground-Water Movement in Pipe Spring National Monument, Arizona
}

\section{Scientific Investigations Report 2004-5082}

Prepared in cooperation with the NATIONAL PARK SERVICE
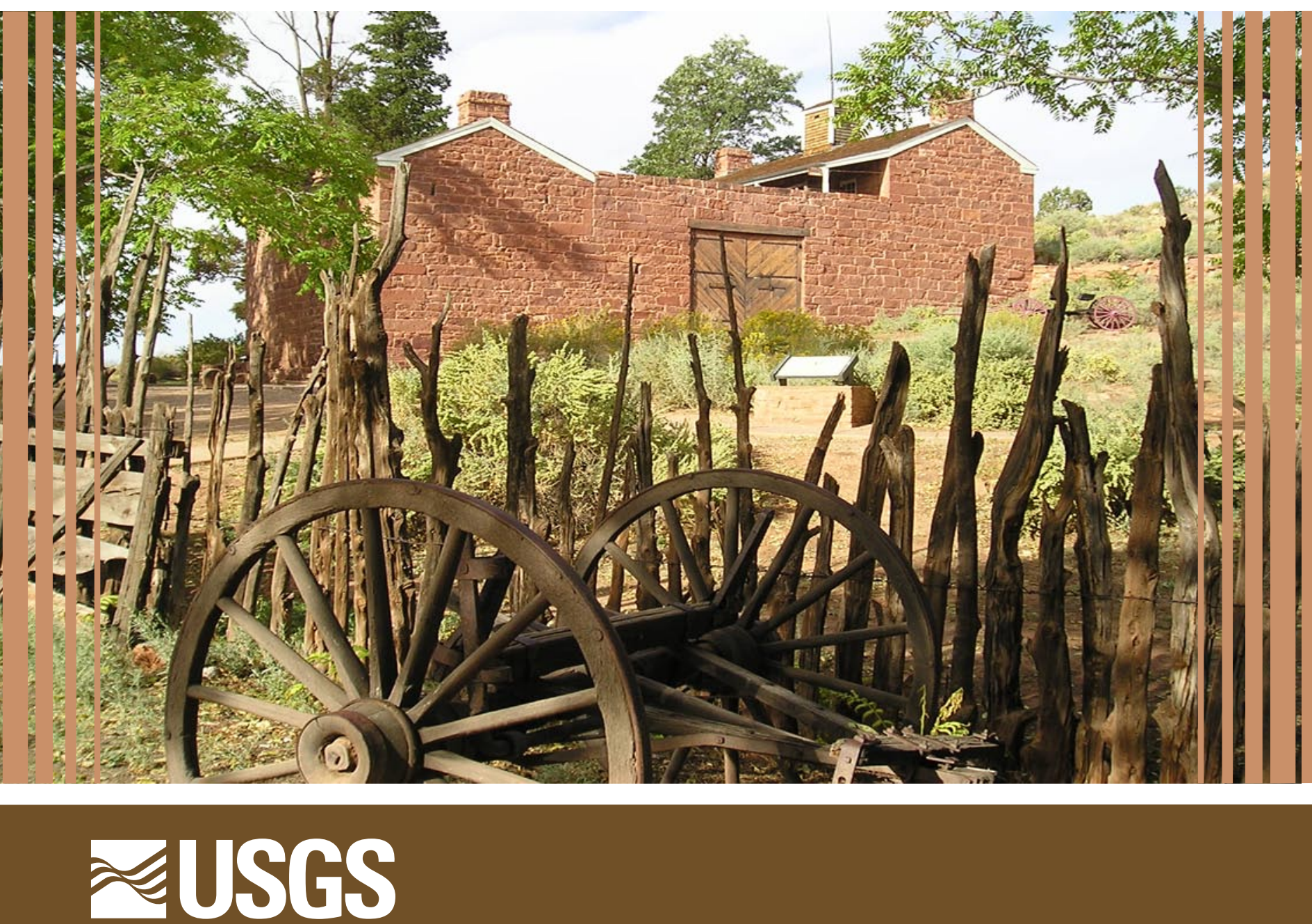
This page left blank intentionally. 


\section{Preliminary Investigation of Structural Controls of Ground-Water Movement in Pipe Spring National Monument, Arizona}

By Margot Truini, J.B. Fleming, and H.A. Pierce

Prepared in cooperation with the

NATIONAL PARK SERVICE

Scientific Investigations Report 2004-5082 


\title{
U.S. Department of the Interior Gale A. Norton, Secretary
}

\author{
U.S. Geological Survey \\ Charles G. Groat, Director
}

\section{U.S. Geological Survey, Reston, Virginia: 2004}

For sale by U.S. Geological Survey, Information Services

Box 25286, Denver Federal Center

Denver, CO 80225-0286

For more information about the USGS and its products:

Telephone: 1-888-ASK-USGS

World Wide Web: http://www.usgs.gov/

Any use of trade, product, or firm names in this publication is for descriptive purposes only and does not imply endorsement by the U.S. Government.

Although this report is in the public domain, permission must be secured from the individual copyright owners to reproduce any copyrighted materials contained within this report.

Suggested citation:

Truini, Margot, Fleming, J.B., and Pierce, H.A., 2004, Preliminary investigation of structural controls of ground-water movement in Pipe Spring National Monument, Arizona: U.S. Geological Survey Scientific Investigations Report 2004$5082,16 p$. 


\section{Contents}

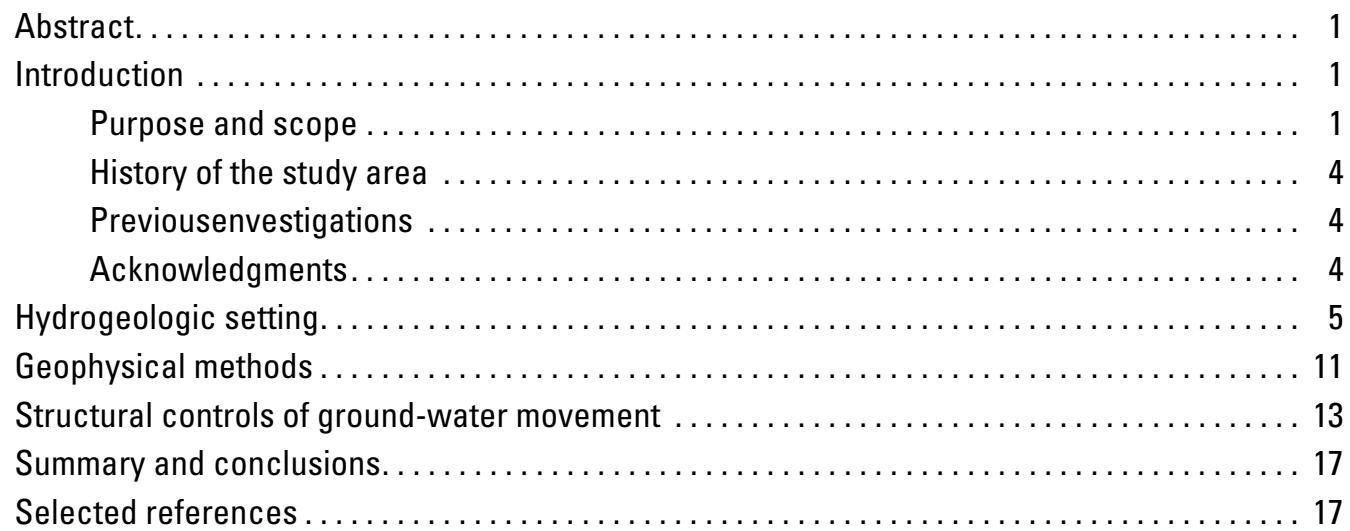




\section{Figures}

Figure 1. Map showing location of study area and wells and springs, Pipe Spring National Monument area, northern Arizona ...................... 2

Figure 2. Graph showing spring discharge, 1976-2003, Pipe Spring National

Monument, northern Arizona . .............................. 3

Figure 3. Map showing surface geology, location of selected EM31 and EM34 lines, and approximate location of spikes in apparent conductivity near Winsor

Point, Pipe Spring National Monument area, northern Arizona ............ 6

Figure 4. Diagram showing generalized lithologic units in the Pipe Spring National Monument area and a photograph showing the sandstone facies of the Kayenta Formation and the Navajo Sandstone at Pipe Spring National Monument, northern Arizona ........................... 8

Figure 5. Photographs showing fractured bedrock of the Kayenta Formation in the open adit during reconstruction of Tunnel Spring in 2001, Pipe Spring National Monument, northern Arizona A. Fractures in the Kayenta Formation ........................ 9

B. Ground-water seepage from fractures in the Kayenta Formation ......... 9

Figure 6. Map showing direction of ground-water movement and locations of seismic and electromagnetic lines in Pipe Spring National

Monument, northern Arizona . .............................. 10

Figure 7. Photograph showing equipment for the seismic profile (line 1) in front of Winsor Castle, Pipe Spring National Monument, northern Arizona .......... 11

Figure 8. Photograph showing electromagnetic-induction (EM) tools, Pipe Spring National Monument, northern Arizona

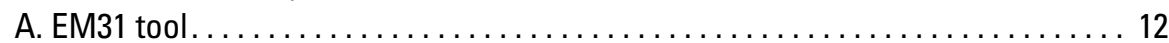

B. EM34 tool. . . . . . . . . . . . . . . . . . . . . . . . . . . . 12

Figure 9. Graph showing eismic-refraction record from line 2 indicating low signal-to-noise ratio, making useful interpretation impossible, Pipe Spring National Monument, northern Arizona .................. 14

Figure 10. Map showing areas of high and low apparent conductivity, Pipe Spring National Monument, northern Arizona ........................ 15

Figure 11. Graphs showing apparent conductivity from EM34 data north of Pipe Spring

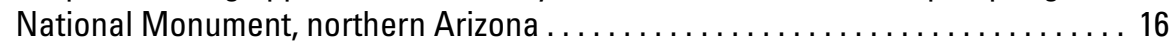

\section{Tables}

Table 1. Nominal depths of exploration for Genoics EM instruments ............... 13 


\section{Conversion Factors and Datum}

\begin{tabular}{rcl}
\hline Multiply & By & To obtain \\
\hline meter $(\mathrm{m})$ & 3.281 & feet \\
kilometer $(\mathrm{km})$ & 0.6214 & mile \\
square kilometer $\left(\mathrm{km}^{2}\right)$ & 247.1 & acre \\
square kilometer $\left(\mathrm{km}^{2}\right)$ & 0.3861 & square mile \\
liter $(\mathrm{L})$ & 0.2642 & gallon \\
cubic meter $\left(\mathrm{m}^{3}\right)$ & 264.2 & gallon \\
\hline
\end{tabular}

Vertical coordinate information is referenced to the National Geodetic Vertical Datum of 1929 (NVGD29) - a geodetic datum derived from a general adjustment of the first-order level nets of both the United States and Canada, formerly called Sea Level Datum of 1929; horizontal coordinate information is referenced to the North American Datum of 1927 (NAD 27). Elevation, as used in this report, refers to distance above or below NGVD 29.

\section{WELL-NUMBERING AND NAMING SYSTEM}

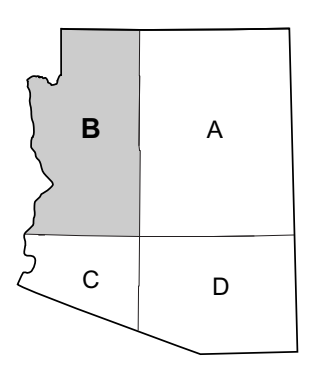

R. 4 W

WELL (B-40-04)08bab1

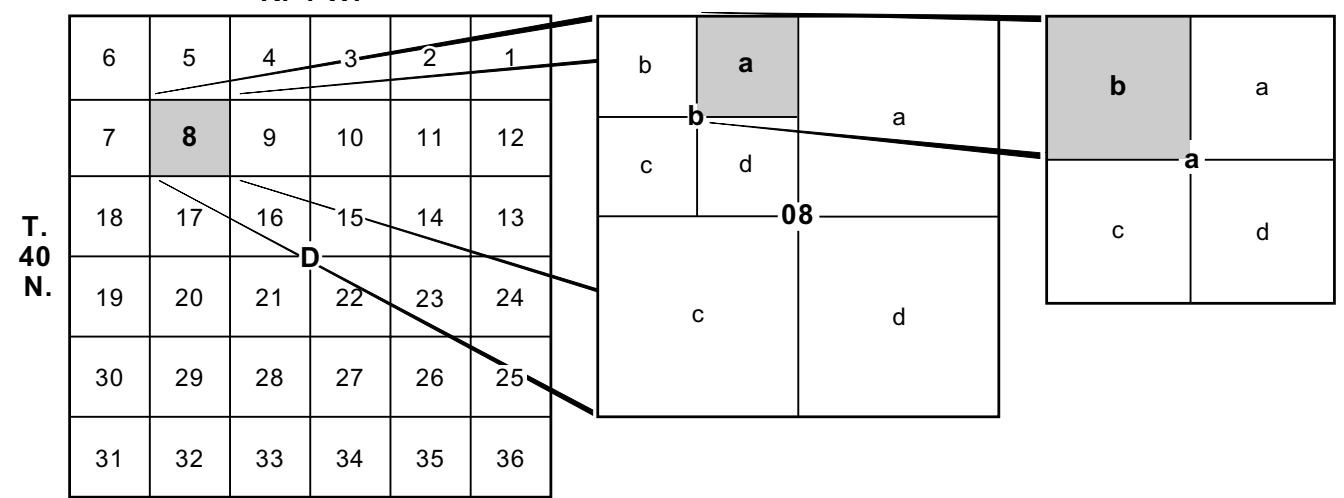

Quadrant B, Township 40 North, Range 4 West, section 8 , quarter section $b$, quarter section a, quarter section $b$, well 1

The well numbers used by the U.S. Geological Survey in Arizona are in accordance with the Bureau of Land Management's system of land subdivision. The land survey in Arizona is based on the Gila and Salt River Meridian and Base Line, which divide the State into four quadrants that are designated by capital letters A, B, C, and D in a counterclockwise direction, beginning in the northeast quarter. The first digit of a well number indicates the township, the second the range, and the third the section in which the well is situated. The lowercase letters a, b, c, and d after the section number indicate the well location within the section. The first letter denotes a particular 160-acre tract, the second the 40 -acre tract, and the third the 10 -acre tract. These letters also are assigned in a counterclockwise direction, beginning in the northeast quarter. If the location is known within the 10 -acre tract, three lowercase letters are shown in the well number. Where more than one well is within a 10 -acre tract, consecutive numbers beginning with 1 are added as suffixes. In the example shown, well number (B-40-04)08bab1 designates the well as being in the NW1/4, NE1/4, NW1/4, section 8, Township 40 North, and Range 4 West. 
This page left blank intentionally 


\title{
Preliminary Investigation of Structural Controls of Ground-Water Movement in Pipe Spring National Monument, Arizona
}

\author{
By Margot Truini, J.B. Fleming, and H.A. Pierce
}

\begin{abstract}
Pipe Spring National Monument, near the border of Arizona and Utah, includes several low-discharge springs that are the primary natural features of the monument. The National Park Service is concerned about the declines in spring discharge. Seismicrefraction and frequency-domain electromagnetic-induction methods were employed in an attempt to better understand the relation between spring discharge and geologic structure. The particular method used for the seismic-refraction surveys was unable to resolve structural features in the monument. Electromagnetic surveys delineated differences in apparent conductivity of the shallow subsurface deposits. The differences are attributable to differences in saturation, lithology, and structure of these deposits.
\end{abstract}

\section{INTRODUCTION}

Pipe Spring National Monument, near the border of Arizona and Utah, is an area of natural and historical interest. Several low-discharge springs are the primary natural features of the monument. The National Park Service (NPS) is concerned about the declines in spring discharge. The discharge at these springs is influenced by geologic structures in the area (George Billingsley, geologist, U.S. Geological Survey, written commun., 2004). The monument is about $24 \mathrm{~km}$ west of Fredonia, Arizona, and $32 \mathrm{~km}$ southwest of Kanab, Utah (fig. 1). The study area is approximately $0.7 \mathrm{~km}^{2}$ and includes the monument, which occupies $0.16 \mathrm{~km}^{2}$ (40 acres) within the boundaries of the Kaibab-Paiute Indian Reservation at the base of the southern tip of Winsor Point on a section of the Vermilion Cliffs, and adjacent areas (fig. 1).

Four springs-West Cabin Spring, Main Spring, Spring Room Spring, and Tunnel Spring - are within the monument boundaries. West Cabin Spring is an undeveloped spring that discharges on the west side of Moccasin Point. Main Spring and Spring Room Spring are two man-made emanation points constructed by the Mormon pioneer occupants of the Pipe Spring ranch from 1870 to 1900 and ostensibly represent the flow of the original natural spring known as Pipe Spring. Tunnel Spring is a horizontal well, hand dug between 1902 and 1907. Since July 1976, the NPS staff have measured discharge monthly at all four springs owing to a concern about declining discharges (Rick Inglis, hydrologist, National Park Service, written commun., 1998). From 1976 to 1986, the combined spring discharges declined about 7.6 L per minute per year (Barrett and Williams, 1986). From 1986 to 2001, combined spring discharge has declined by about $1.9 \mathrm{~L}$ per minute per year (Terry Strong, Facility Manager, National Park Service, written commun., 2001). During this recent period, discharge from West Cabin Spring has remained steady, discharges from Spring Room Spring and Main Spring have dropped to immeasurable levels, and the discharge from Tunnel Spring has increased (fig. 2).

The U.S. Geological Survey (USGS), in cooperation with the NPS, conducted preliminary geophysical surveys during September 1999 to gain a better understanding of how geologic structure controls the relation between ground-water movement and spring discharge in the monument. Seismic refraction and frequency-domain electromagnetic-induction (EM) methods were employed. Four seismic-refraction surveys were conducted around Winsor Castle near Main Spring and Spring Room Spring. Multiple EM31 and EM34 surveys were conducted along transects near the four springs within the monument boundary and along transects north of the monument boundary.

\section{Purpose and Scope}

The purpose of this report is to describe the results of the geophysical surveys that were conducted to help define the subsurface geologic structure that controls ground-water movement within the monument and in areas north of the monument. The report provides information regarding the effectiveness of the methods employed. General structural controls within and north of the monument are described in relation to spring discharges. 


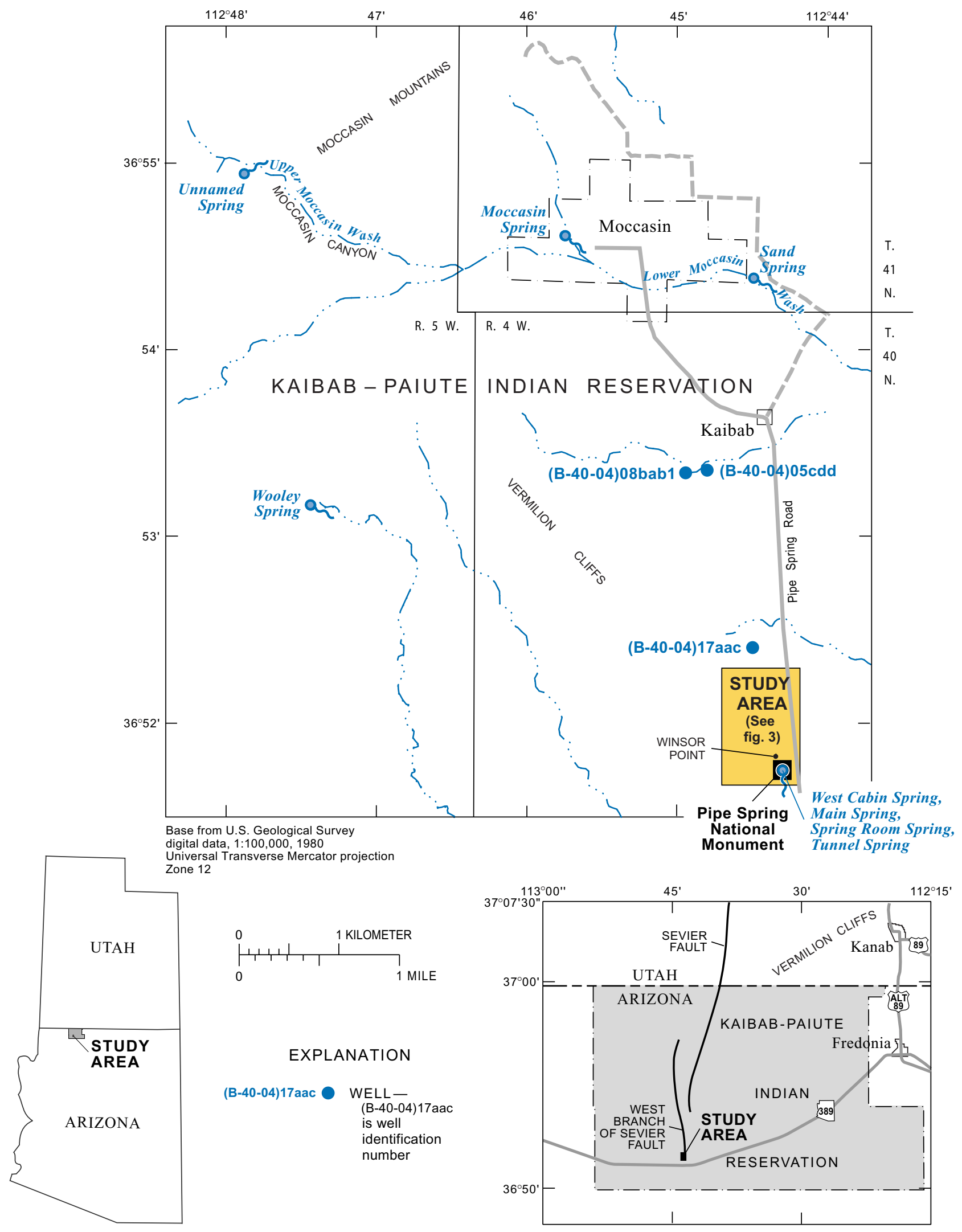

Figure 1. Location of study area and wells and springs, Pipe Spring National Monument area, northern Arizona. 
Introduction 3

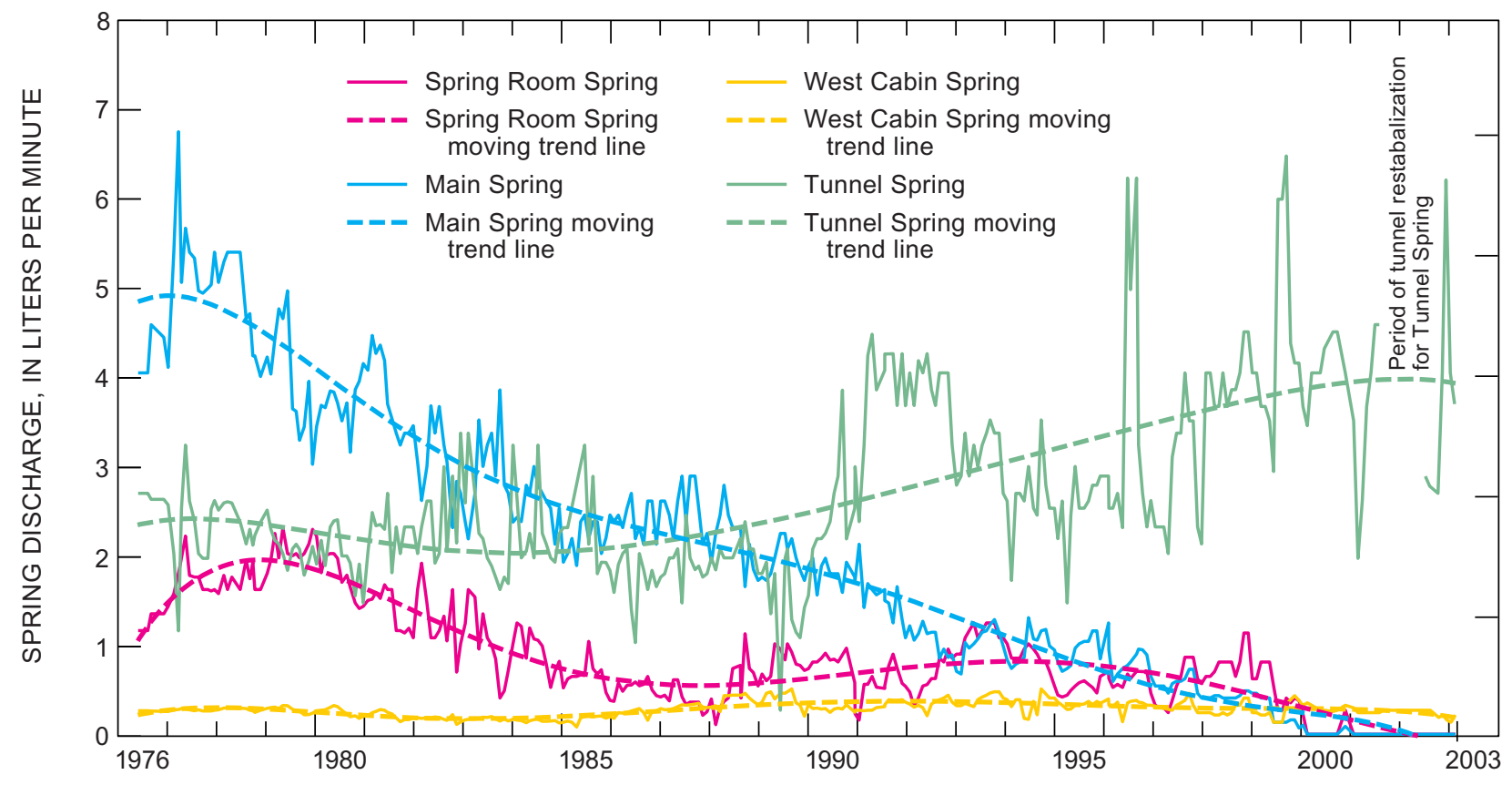

Figure 2. Spring discharge, 1976-2003, Pipe Spring National Monument, northern Arizona. 


\section{Preliminary Investigation of Structural Controls of Ground-Water Movement in Pipe Spring National Monument, Arizona}

\section{History of the Study Area}

Archeological evidence indicates that the riparian resources supported by the springs in the monument have attracted people to the site for the past 8,000 years. Spring flow was the major source of drinking water in the 1870s during the establishment of Winsor Castle and the associated Mormon cattle-ranching operations. Winsor Castle was built directly over Pipe Spring to establish a secure drinking-water supply in an otherwise arid land. As Mormon cattle ranching developed, the springs supplied water for orchards, vegetable gardens, and livestock. In 1923, the monument was established around Winsor Castle to preserve the site of the historic Mormon cattle-ranching operations (Inglis, 1997).

Early modifications to the water-supply systems of the monument included adding cisterns and pipelines from the springs to supply water for ranch operations (Inglis, 1997). Parts of the historic water-distribution system in the monument, such as rock-work channels and ponds, are maintained. Drains and pipelines have been installed to stabilize the buildings against damage from moisture. The pipeline from Tunnel Spring that conveys water outside the monument was replaced in 1988 to maintain water-use agreements with the local cattlemen's association. The adit that forms Tunnel Spring was reconstructed in 2001 to prevent imminent collapse and ensure continued water availability to the cattlemen and monument. In 1971, NPS Culinary well (B-40-04)05cdd was drilled outside the monument to meet the increasing needs of the monument and the Kaibab-Paiute Tribe (E.H. McGavock, hydrologist, U.S. Geological Survey, written commun., 1974).

\section{Previous Investigations}

During 1972-74, the USGS evaluated the quantity and quality of available ground water from the Shinarump Member of the Chinle Formation and the potential for ground-water development in the Navajo Sandstone near the village of Kaibab (Gary Levings, hydrologist, U.S. Geological Survey, written commun., 1974). Levings found that ground water from the Shinarump Member contained concentrations of sulfate in excess of recommended levels for public supply (U.S. Public Health Service, 1962) and that ground water from the Navajo Sandstone was suitable for domestic use (Gary Levings, hydrologist, U.S. Geological Survey, written commun., 1974). Levings also stated that large-scale pumping of ground water from the Navajo Sandstone near Moccasin or the monument might decrease flow to the springs in these areas.

Barrett and Williams (1986) evaluated the declining spring flows in the monument and analyzed spring-flow data from 1976 to 1986 with respect to water quality, precipitation, and geology. They concluded that the decline in spring flow probably was the result of ground-water pumping in the area rather than of natural variations in precipitation.

Inglis (1997) examined precipitation data and data collected from the springs at the monument, from Moccasin Spring, and from wells (B-40-04)17aac and (B-40-04)05cdd (fig. 1), and was not able to establish a correlation between precipitation and the declining spring discharges. From August 1990 to June 1992, Inglis (1997) measured water levels at wells (B-40-04)08bab1 and (B-40-04)17aac (fig. 1) and spring discharges at the monument. He concluded that the cause of annual fluctuations in ground-water levels and spring discharges, whether it be variations in seasonal recharge, seasonal pumping from wells, or a combination of these factors, could not be determined at that time.

Truini (1998) characterized the ground-water system in the western part of the Kaibab-Paiute Indian Reservation from north of Moccasin, Arizona, to the monument. She determined ground-water flow direction and used geochemical methods to determine ages of ground water and recharge characteristics. She concluded that ground-water movement is from north to south, that the ground water is between 200 and 9,000 years old, and that components of recharge to ground water within the study area are from the same source. Within the study area, estimated ground-water withdrawals were greater than the estimated recharge.

\section{Acknowledgments}

John Hiscock (NPS, Superintendent of Pipe Spring National Monument), Dave Sharrow (NPS, Hydrologist, National Park Service), Terry Strong (NPS, Facility Manager, Pipe Spring National Monument), and other staff of the NPS helped in the organization and collection of geophysical data. Members of the Kaibab Band of the Paiute Tribe gave permission to access study areas and helped with the collection of geophysical data. 


\section{HYDROGEOLOGIC SETTING}

The study area encompasses Winsor Point at the southern end of a section of the Vermilion Cliffs (fig. 3). This section of the Vermilion Cliffs is a monocline resulting from Laramide (late Cretaceous to Paleocene) folding and subsequent faulting (George Billingsley, geologist, U.S. Geological Survey, written commun., 2003).

The west segment of the Sevier Fault branches from the main segment just north of Pipe Spring National Monument. Associated with the west segment is an east-dipping monocline herein referred to as the Moccasin Monocline. At the base of the Moccasin Monocline is a small syncline that parallels the strike of the monocline [fig. 3].

The west segment of the Sevier Fault, the Moccasin Monocline, and the syncline all gradually die out northward into Moccasin Mountain about $3.2 \mathrm{~km}$ north of Moccasin, Arizona. The monocline and syncline extend southwest of Pipe Spring National Monument. The syncline is subtly visible in the monoclinal flex in the Vermilion Cliffs just west of the monument. The fault, monocline, and syncline parallel the paved road between the monument and Moccasin, Arizona. The northwest trend of the west segment of the Sevier Fault may be continuous as a small fault at depth in the Precambrian basement rocks under Moccasin Mountain and reconnect to the main segment of the Sevier Fault near Sand Canyon Wash just south of the Arizona/Utah State line. (George Billingsley, geologist, U.S. Geological Survey, written commun, 2003.)

The Navajo Sandstone and the upper facies of the Kayenta Formation form the unconfined fractured rock aquifer from which ground water discharges at springs in the monument (fig. 4; Truini, 1998). On the basis of water-level measurements in area wells, ground-water movement is from north to south along the Vermilion Cliffs (Truini, 1998). Finegrained sediments below the upper sandstone facies of the Kayenta Formation behave as a confining unit that restricts vertical ground-water movement, forcing the water to move along the bedding planes and fractures in the Navajo Sandstone and upper facies of the Kayenta Formation (fig. 4). Displacement along the Sevier Fault in the southern part of the ground-water flow path has placed the older Triassic Schnabkaib Member of the Moenkopi Formation on the east side of the Sevier Fault against the younger Kayenta Formation and Navajo Sandstone on the west side of the Sevier fault (George Billingsley, geologist, U.S. Geological Survey, written commun., 2003.). The Schnabkaib Member forms a semi-impermeable boundary, preventing water from moving west to east across the Sevier Fault.

Spring discharge within the monument issues from the sandstone facies of the Kayenta Formation (fig. 4). During reconstruction of the adit for Tunnel Spring in 2001, ground water was observed seeping from the direction of West Cabin Spring (the northwest side of the open trench) through small fractures in the Kayenta Formation at an elevation of 1,502 m ( $\pm 0.6 \mathrm{~m}$; fig. 5). The elevation of the uppermost discharge point for West Cabin Spring is $1,515 \mathrm{~m}$, and the measured elevation at Main Spring is $1,511 \mathrm{~m}$. The NPS has confirmed that Main Spring and Spring Room Spring are hydraulically connected and are considered to discharge from the same ground-water source (fig. 6; David Sharrow, hydrologist, National Park Service, oral commun., 2002). On the basis of the visual observation in the Tunnel Spring adit and the differences in elevation between West Cabin Spring and Main Spring, it is likely that ground water within the monument moves from the area of West Cabin Spring to the southeast (fig. 6) 


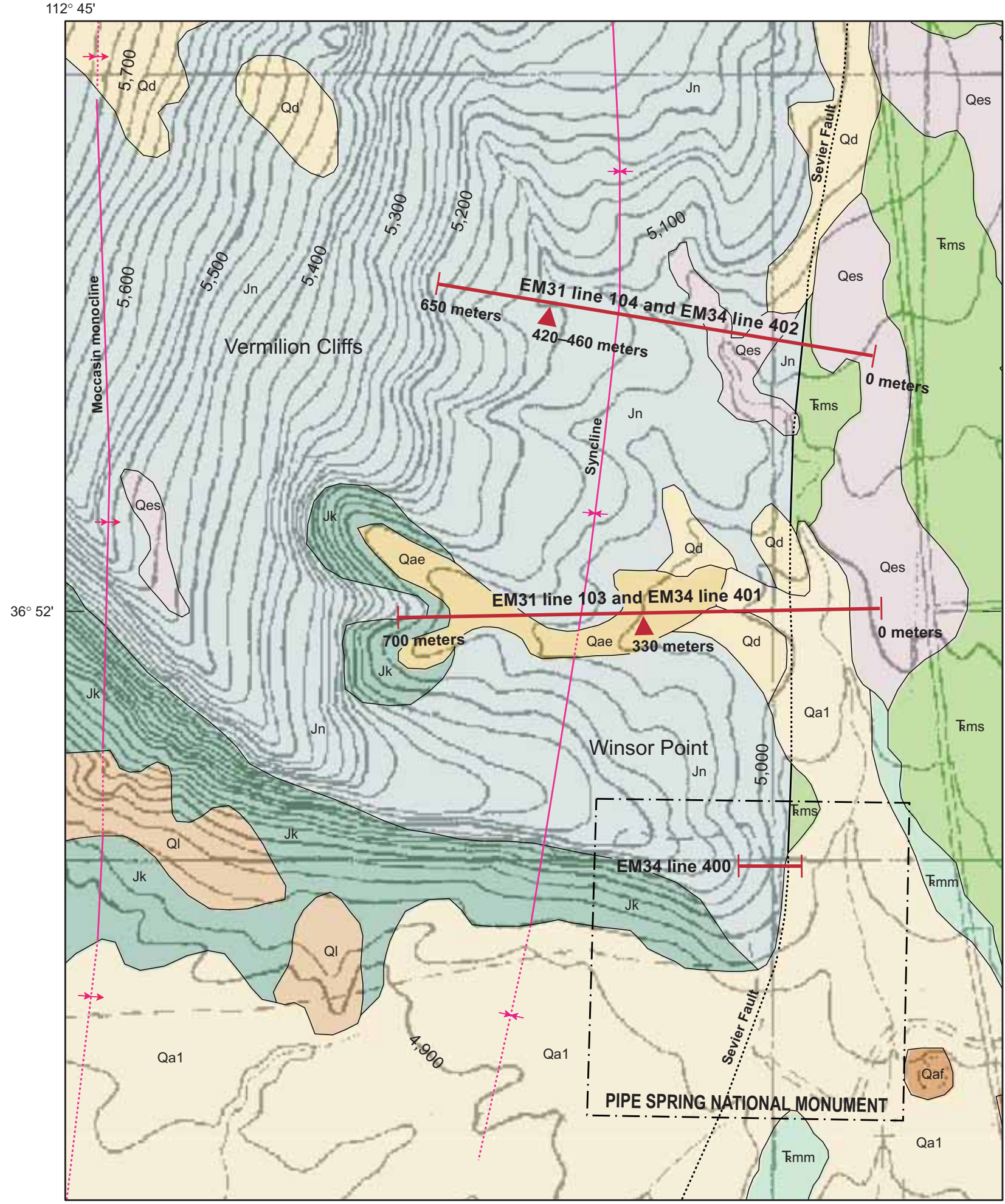

Base from U.S. Geological Survey, 1:24,000, Moccasin Kaibab, Pipe Valley, and Pipe Spring; 1988

Universal Transverse Mercator Projection 1927 North

American Datum Clark 1866 Ellipsoid, Zone 12

Geology from George Billingsley and others, U.S. Geological Survey, written commun., 2003

\begin{tabular}{|c|c|c|c|c|c|}
0 & 0.25 KILOMETER \\
0 & CONTOUR INTERVAL 20 FEET (6.10 METERS)
\end{tabular}

Figure 3. Surface geology, location of selected EM31 and EM34 lines, and approximate location of spikes in apparent conductivity near Winsor Point, Pipe Spring National Monument area, northern Arizona. 


\section{EXPLANATION}

SURFICIAL DEPOSITS

Qaf

Qes

Qd

Qae

Qa1

QI

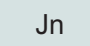

Jk

kms

Kmm
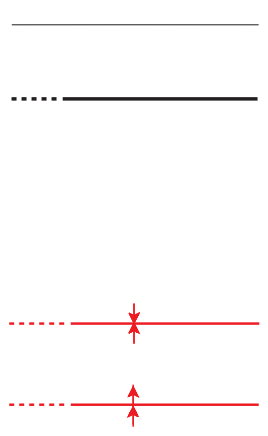

$\Delta$

330 meters
Artificial fill and quarries (Holocene)

Eolian sand sheet deposits (Holocene)

Eolian sand dune deposits (Holocene)

Mixed eolian and fluvial deposits (Holocene)

Young alluvial fan deposits (Holocene)

Landslide debris deposits (Holocene and Pleistocene)

SEDIMENTARY ROCKS

Navajo Sandstone (Lower Jurassic)

Kayenta Formation (Lower Jurassic)

Schnabkaib Member of Moenkopi Formation (Lower Triassic)

Middle Red Member of Moenkopi Formation (Lower Triassic)

CONTACT -Approximate contact for alluvial units only

FAULT - Dotted where concealed. Faults shown as bounding alluvium do not offset alluvium

FOLDS - Showing trace of axial surface and direction of plunge. Dotted where concealed

Syncline

Monocline

Approximate location of the spikes in apparent conductivity

Figure 3. Continued. 
8 Preliminary Investigation of Structural Controls of Ground-Water Movement in Pipe Spring National Monument, Arizona

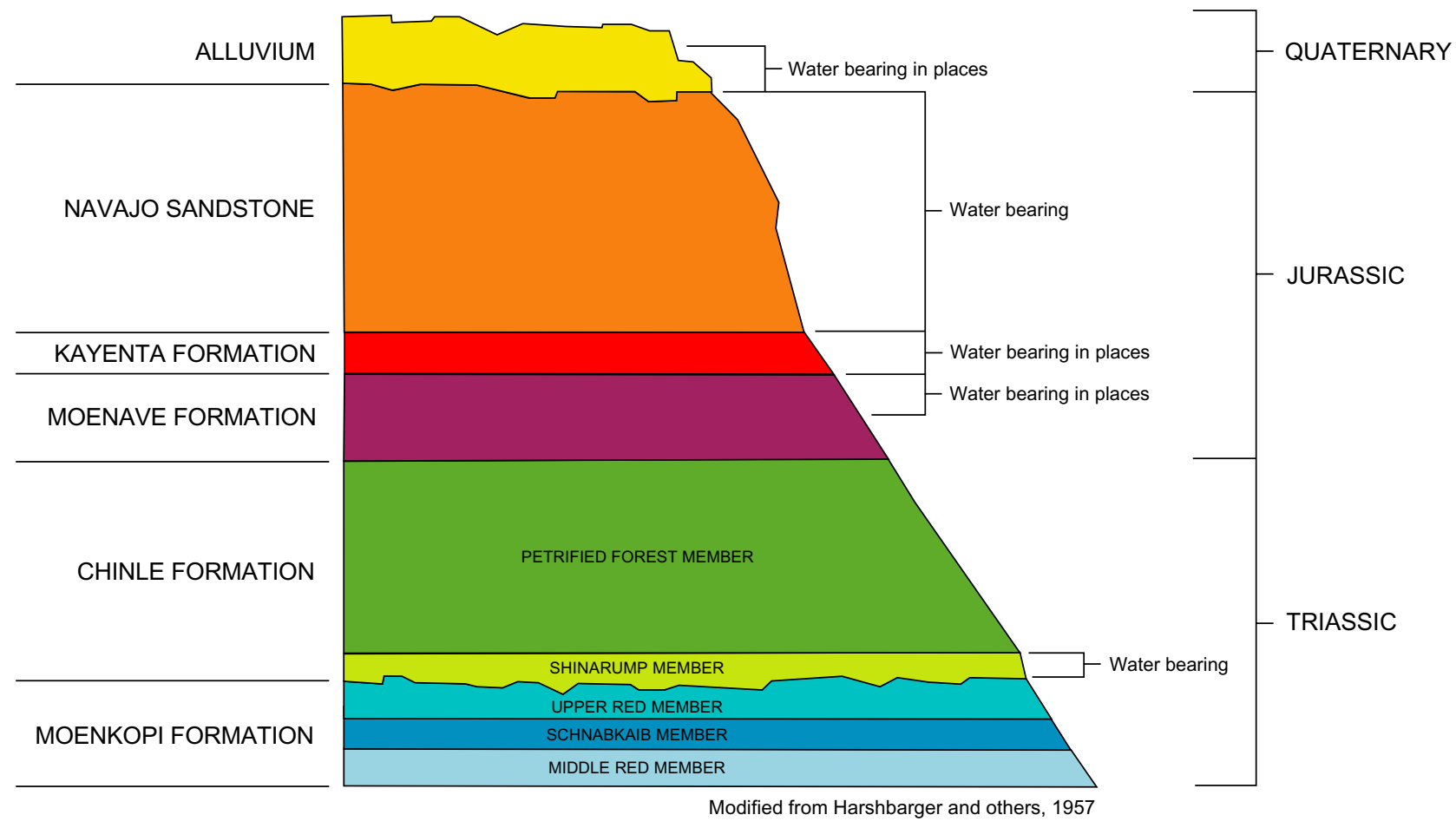

Geologic contact between the Kayenta Formation and the Navajo Sandstone, and fractures and bedding plane in the upper sandstone facies of the Kayenta Formation and the Navajo Sandstone.

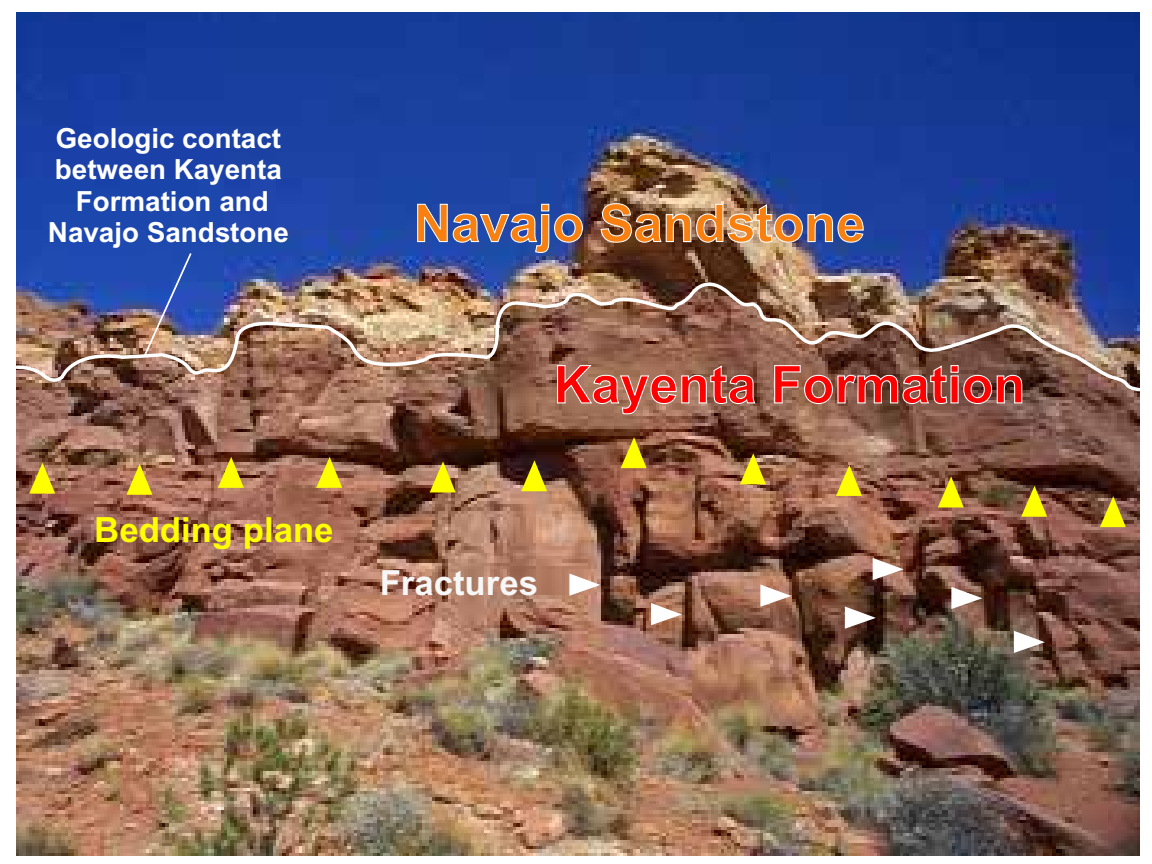

Figure 4. Generalized lithologic units in the Pipe Spring National Monument area and a photograph showing the sandstone facies of the Kayenta Formation and the Navajo Sandstone at Pipe Spring National Monument, northern Arizona. 
A.

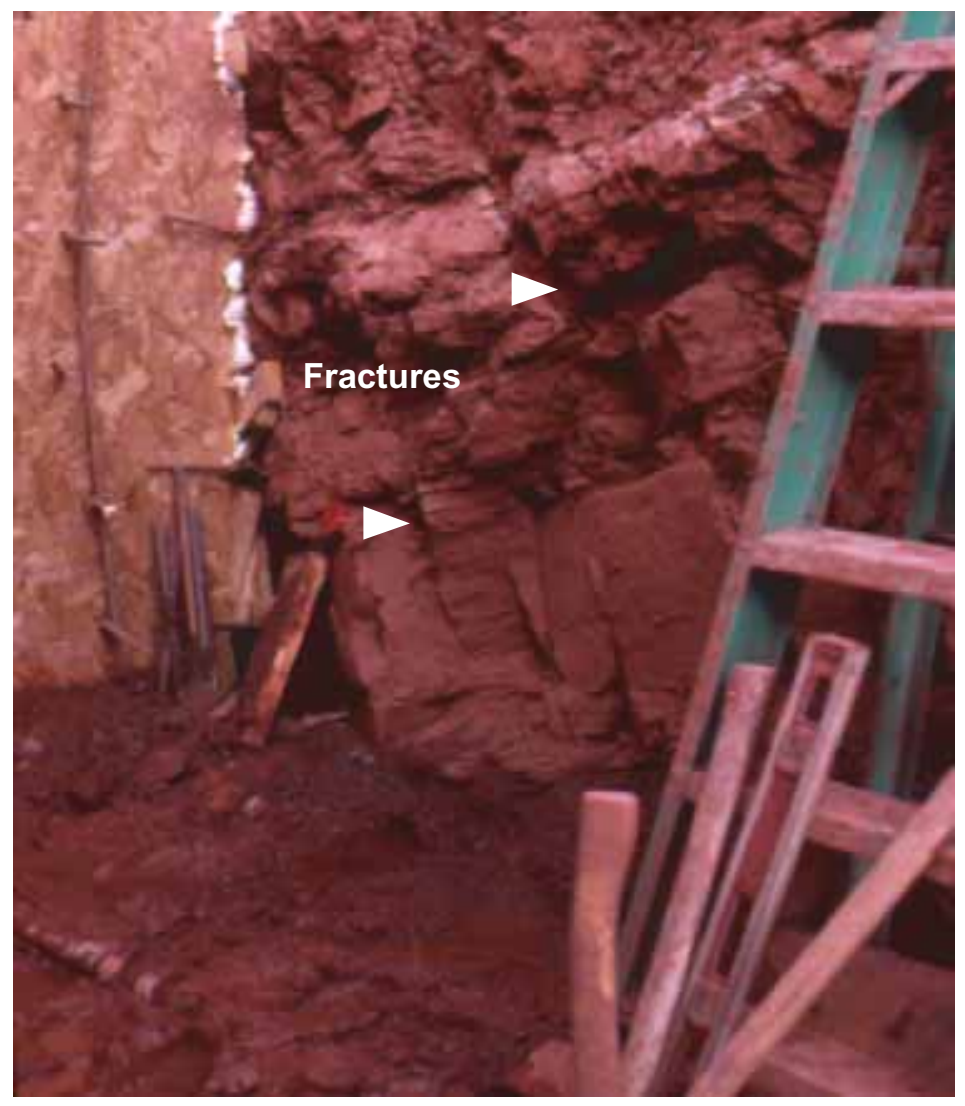

B.

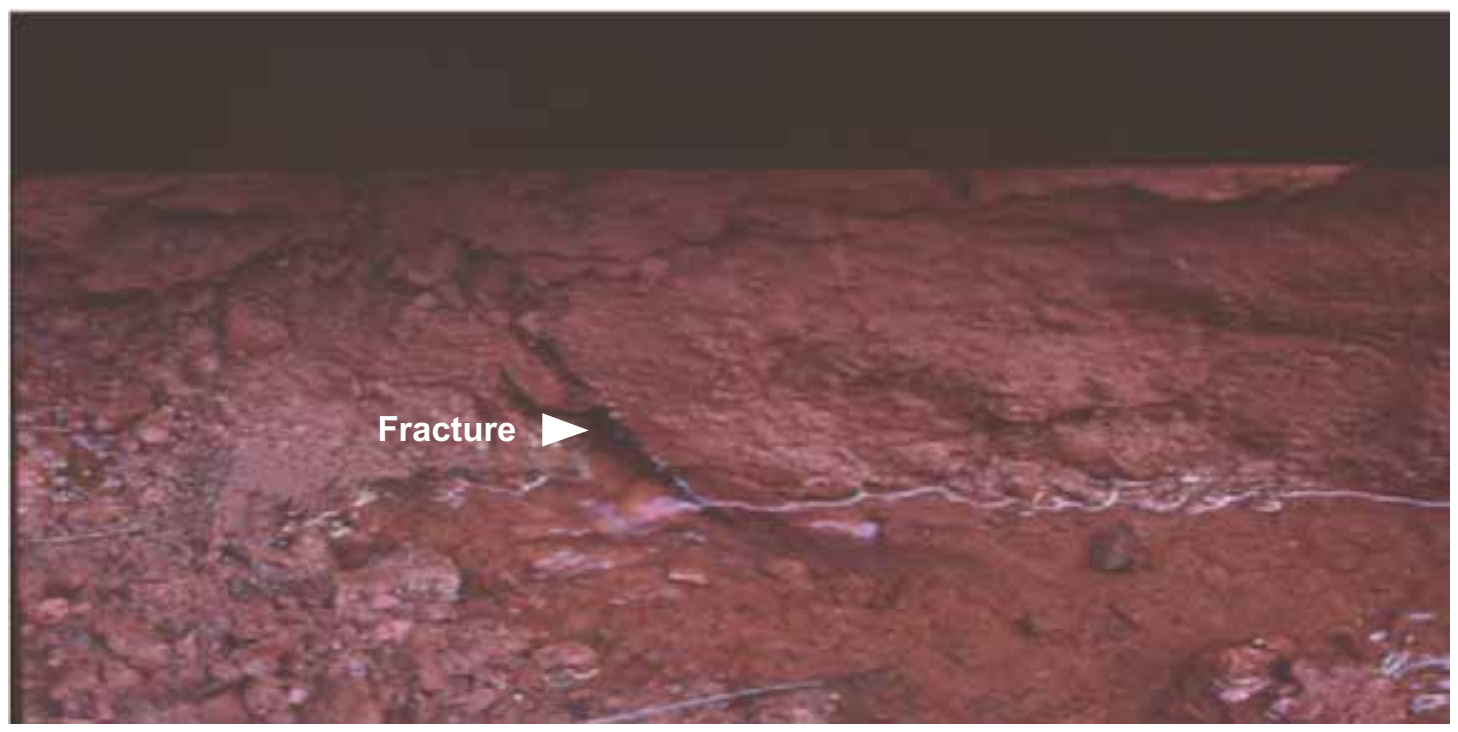

Figure 5. Fractured bedrock of the Kayenta Formation in the open adit during reconstruction of Tunnel Spring in 2001, Pipe Spring National Monument, northern Arizona. A, Fractures in the Kayenta Formation. B, Ground-water seepage from fractures in the Kayenta Formation. 


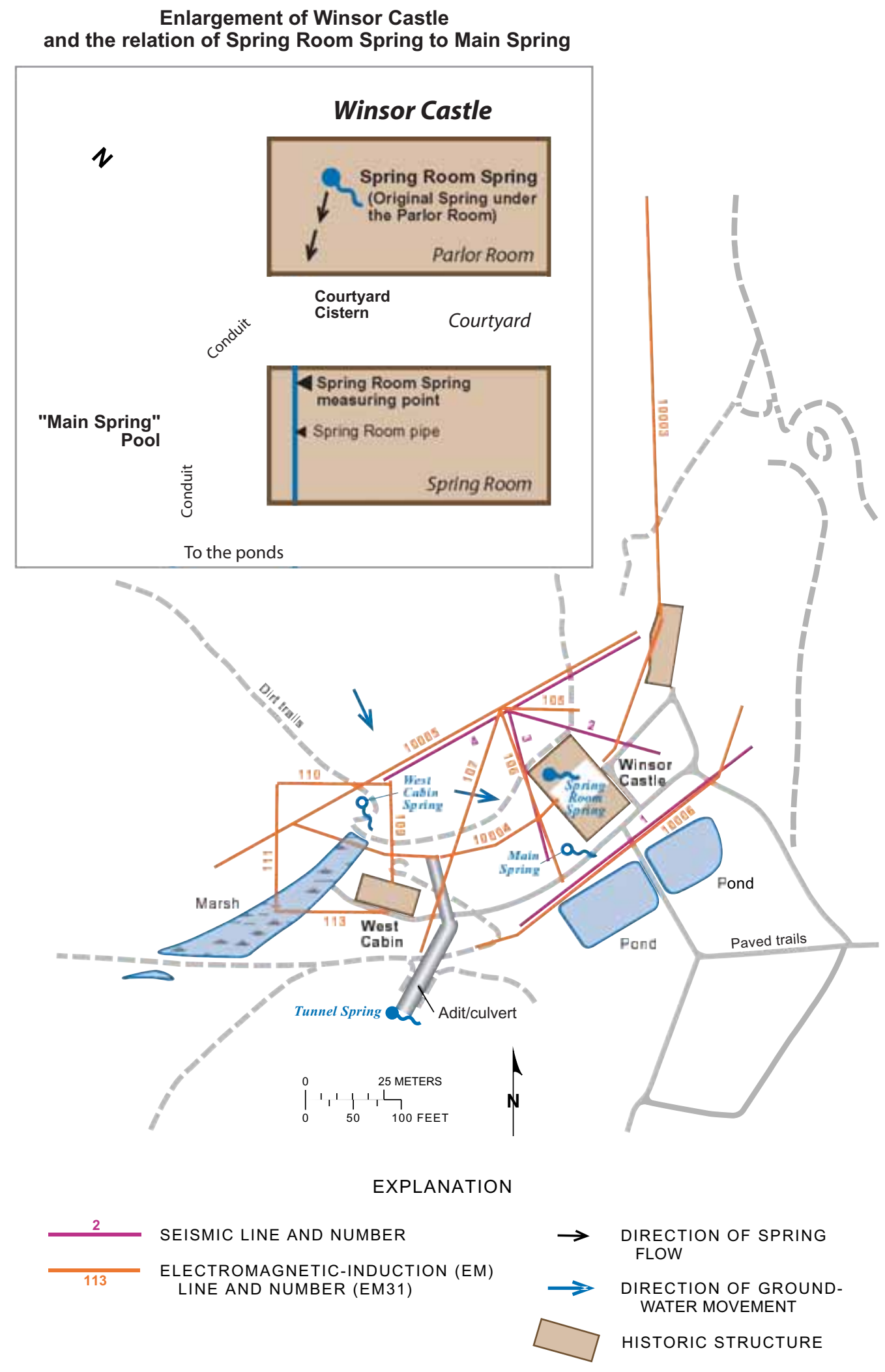

Figure 6. Direction of ground-water movement and locations of seismic and electromagnetic lines in Pipe Spring National Monument, northern Arizona. 


\section{GEOPHYSICAL METHODS}

Seismic and electromagnetic techniques were used in the study. The shallow seismic-refraction method was used in the seismic surveys, and EM31 and EM34 tools (Geonics, Inc.) were used in the electromagnetic surveys.

Application of the seismic-refraction method is based on the assumptions of two subsurface layers that have different seismic velocity; the travel time is determined from refracted seismic waves at the interface between the two layers. Seismic energy is generated using a source known as a 'shot,' and for shallow application this usually is a hammer and (or) a small explosive. Seismic-refraction data were collected within the monument boundaries using a 48-channel seismograph (Geometrics, Inc.). Compressional waves were generated using a small explosive source (8-gauge black powder charge). Shots were set off 5 and $10 \mathrm{~m}$ from each end of the four seismic survey lines.

Seismic-refraction data were collected along transect lines near Winsor Castle (figs. 6 and 7). Seismic lines 1 and 4 were parallel to one another and oriented northeast-southwest. Seismic lines 2 and 3 had a common starting point and were oriented northwest-southeast. Each survey line consisted of 48 geophones spaced at either 1- or 2-m intervals (fig. 7). Data were recorded on a seismograph and then transferred to a computer where the refraction records could be used to construct travel-time curves. Because the refraction records were not sufficient to construct travel-time curves, a depth profile of subsurface layers delineated by seismic velocity could not be constructed.

The electromagnetic-induction instruments (EM31 and EM34; fig. 8A, $\boldsymbol{B}$ ) were used to measure the apparent electrical conductivity, in millisiemens per meter, of the subsurface within the monument and in the area north of the monument. The depth of exploration depended on the separation between the transmitter coil and receiver as well as on the coil orientations. Eight configurations of coil separation and orientation are summarized in table $\mathbf{1}$.

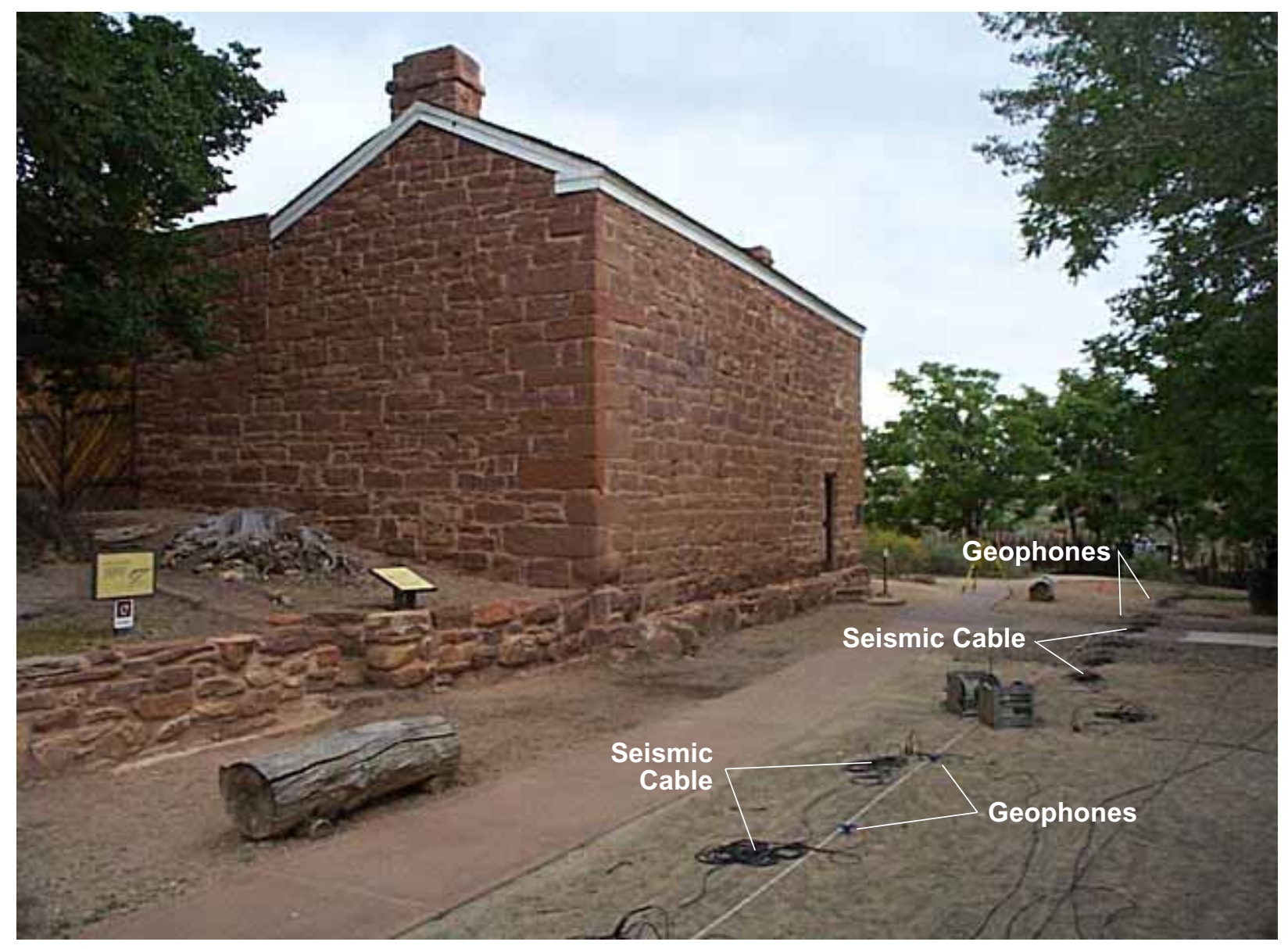

Figure 7. Equipment for the seismic profile (line 1) in front of Winsor Castle, Pipe Spring National Monument, northern Arizona. 
A.

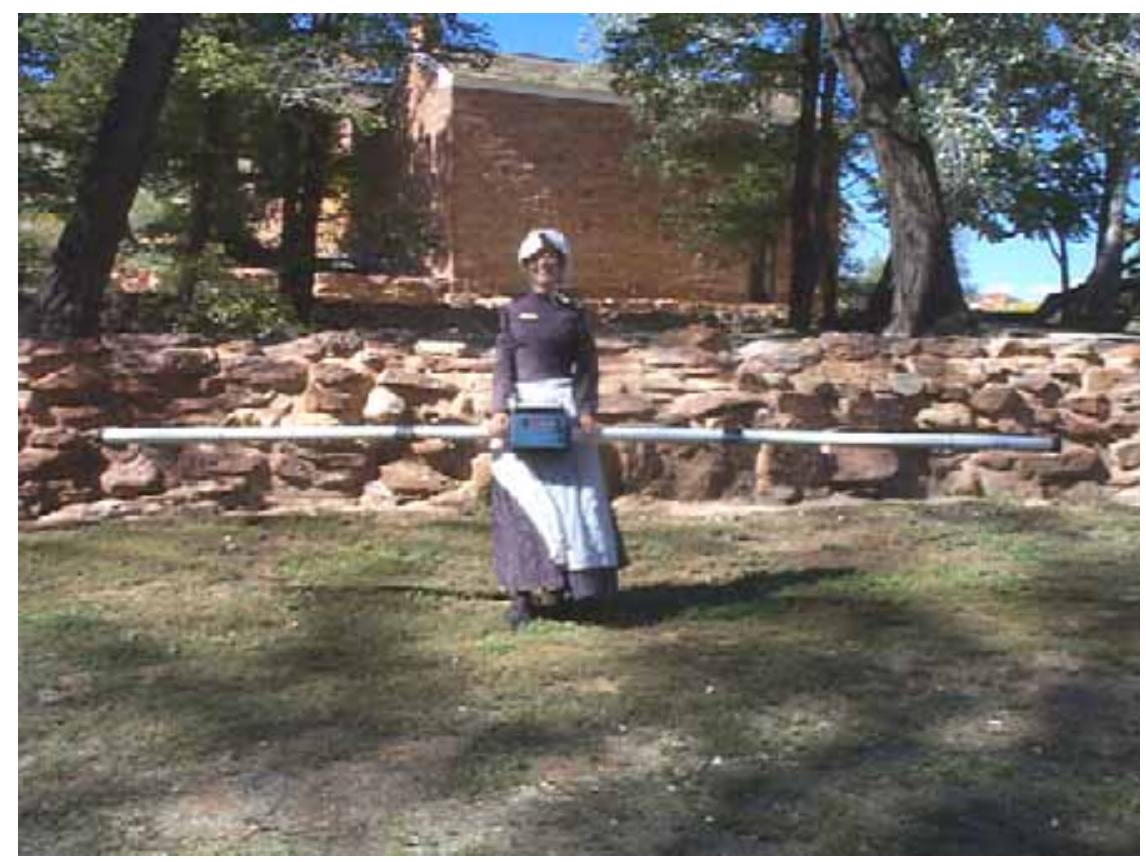

B.

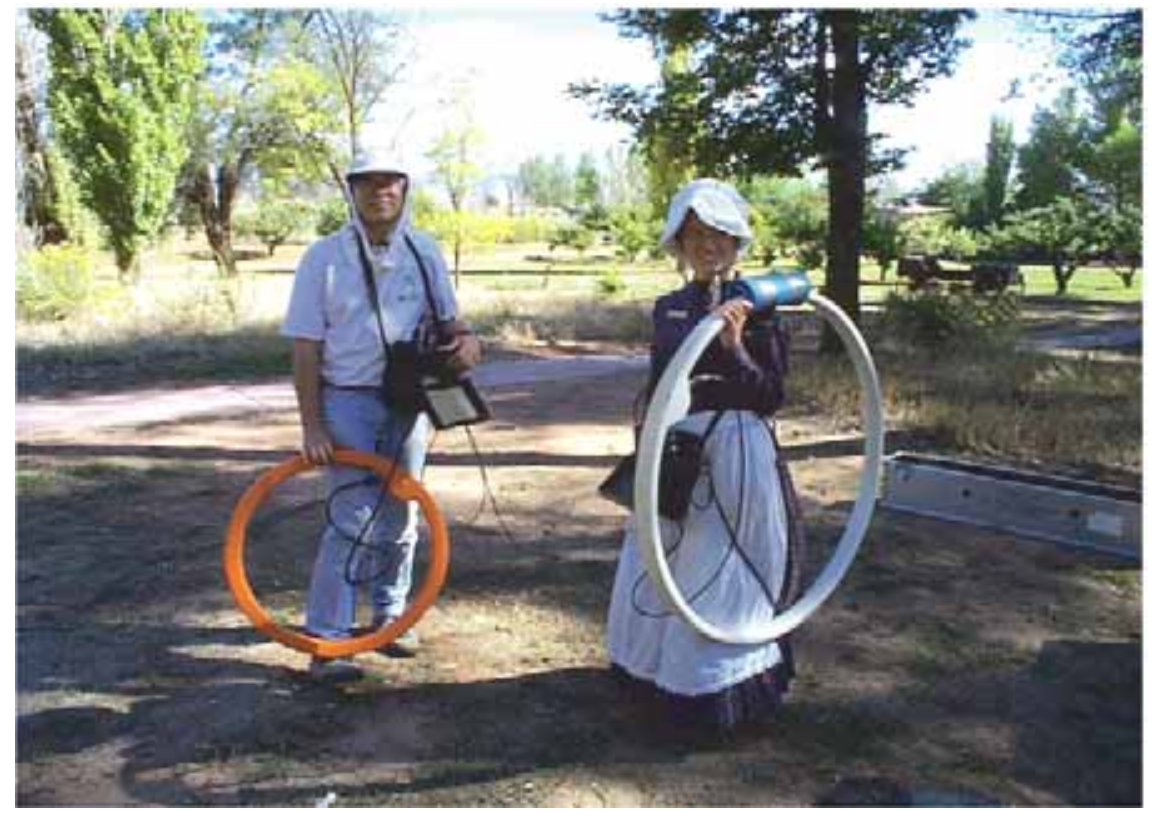

Figure 8. Electromagnetic-induction (EM) tools, Pipe Spring National Monument, northern Arizona. $A$, EM31 tool. $B$, EM34 tool. 
Table 1. Nominal depths of exploration for Geonics EM instruments

[From Northwest Geophysical Associates, Inc. (2000). Depth of exploration is depth above which 67 percent of the signal originates in a uniform earth $\mathrm{HD}$, horizontal dipole; VD, vertical dipole]

\begin{tabular}{lccc}
\hline Instrument & $\begin{array}{c}\text { Coil } \\
\text { separation, } \\
\text { in meters }\end{array}$ & Orientation & $\begin{array}{c}\text { Nominal depth } \\
\text { of exploration, } \\
\text { in meters }\end{array}$ \\
\hline EM31 & 3.7 & HD & 2.5 \\
EM31 & 3.7 & VD & 5.2 \\
EM34 & 10 & HD & 6.8 \\
EM34 & 10 & VD & 14.3 \\
EM34 & 20 & HD & 13.5 \\
EM34 & 20 & VD & 28.6 \\
EM34 & 40 & HD & 27 \\
EM34 & 40 & VD & 57 \\
\hline
\end{tabular}

Measurements of apparent conductivity included thirteen 100-series EM31 transects and three 400-series EM34 transects within the monument and north of the monument boundary (figs. 3 and 6). EM31 measurements use vertical dipole (VD) and horizontal dipole (HD) orientations. These orientations provide two data points per station on the EM31 lines. The EM34 uses VD and HD orientations with three separations $(10 \mathrm{~m}, 20 \mathrm{~m}$, and $40 \mathrm{~m})$ at each station. These configurations provide six data points per station. The different orientations and separations provide information about the apparent conductivity of the earth at different depths in millisiemens per meter. The deeper VD orientations for both the EM31 and the EM34 were used to characterize the apparent conductivity for the purposes of this report.

EM31VD data were used to create contour maps of the measured apparent conductivity within the monument as a means of characterizing relative differences in conductivity. Analysis of data from the two EM31 lines (103 and 104) north of the monument are not presented in this report because the depth of exploration for these lines (table 1) was shallower than that for the corresponding EM34 lines and analysis of the EM31 data was concurrent with that of the EM34 data.

EM34 VD data for the three separations $(10 \mathrm{~m}, 20 \mathrm{~m}$, and $40 \mathrm{~m}$ ) were plotted for lines 401 and 402 north of the monument (fig. 3). The plots were used to examine the apparent conductivity at the depths associated with the three coil spacings (table 1). Measurements from EM34 line 400 are not described in this report because the line was short and the results were inconclusive.

\section{STRUCTURAL CONTROLS OF GROUND-WATER MOVEMENT}

Geophysical surveys using seismic-refraction and EM techniques were partially successful in delineating structural controls of ground-water movement. Lithologic and structural features could not be distinguished from the seismic-refraction data; however, data from the EM31 and EM34 surveys revealed patterns in apparent conductivity.

The lithology and structure of the rocks near Winsor Point attenuated the acoustic energy from the seismic-refraction surveys which resulted in low signal-to-noise ratios. At the time of the seismic-refraction surveys, the subsurface lithology was poorly understood, and the method employed was unable to produce a clear signal to delineate distinct layers on the basis of seismic velocity (fig. 9).

Contours of apparent conductivity revealed areas of high and low apparent conductivity within the monument. An area of low apparent conductivity (10-30 millisiemens per meter), between Winsor Castle and West Cabin, exists between two areas of high apparent conductivity (greater than 40 millisiemens per meter; fig. 10). The zone of high apparent conductivity to the west is likely associated with saturated fine-grained sediments of the Kayenta Formation near West Cabin Spring where ground water discharges on a slope and creates a marshy area (fig. 10). The area of high apparent conductivity to the east may also reflect saturated conditions near the land surface. The steep gradient in apparent conductivity between the areas of high and low conductivity, represented by the blue and light blue areas, respectively, on figure 10 indicate the likelihood of north-south trending fractures that could provide secondary permeability for ground-water movement and control the location of spring discharge.

EM34 VD data from lines 401 and 402 appear to correlate to the structural positions of units attributable to the Moccasin Monocline, the associated syncline, and the Sevier Fault, and to lithologic differences among the geologic units in the subsurface (George Billingsley, geologist, U.S. Geological Survey, written commun., 2004; fig. 3). Apparent conductivity data correspond to the change in lithology from the shale and clay sediments of the Schnabkaib Member of the Moenkopi Formation to the sandstone sediments of the Navajo Sandstone and the shaly sediments of the Kayenta Formation across the Sevier Fault between 120 and $220 \mathrm{~m}$ from the east end of EM34 line 402 (figs. 3 and 11A). The difference in the apparent conductivity measured using the 10- and 20-m spacings compared to that measured using the $40-\mathrm{m}$ spacing is much greater from 220 to $650 \mathrm{~m}$ along the line than from 0 to $220 \mathrm{~m}$ (fig. 11A). 


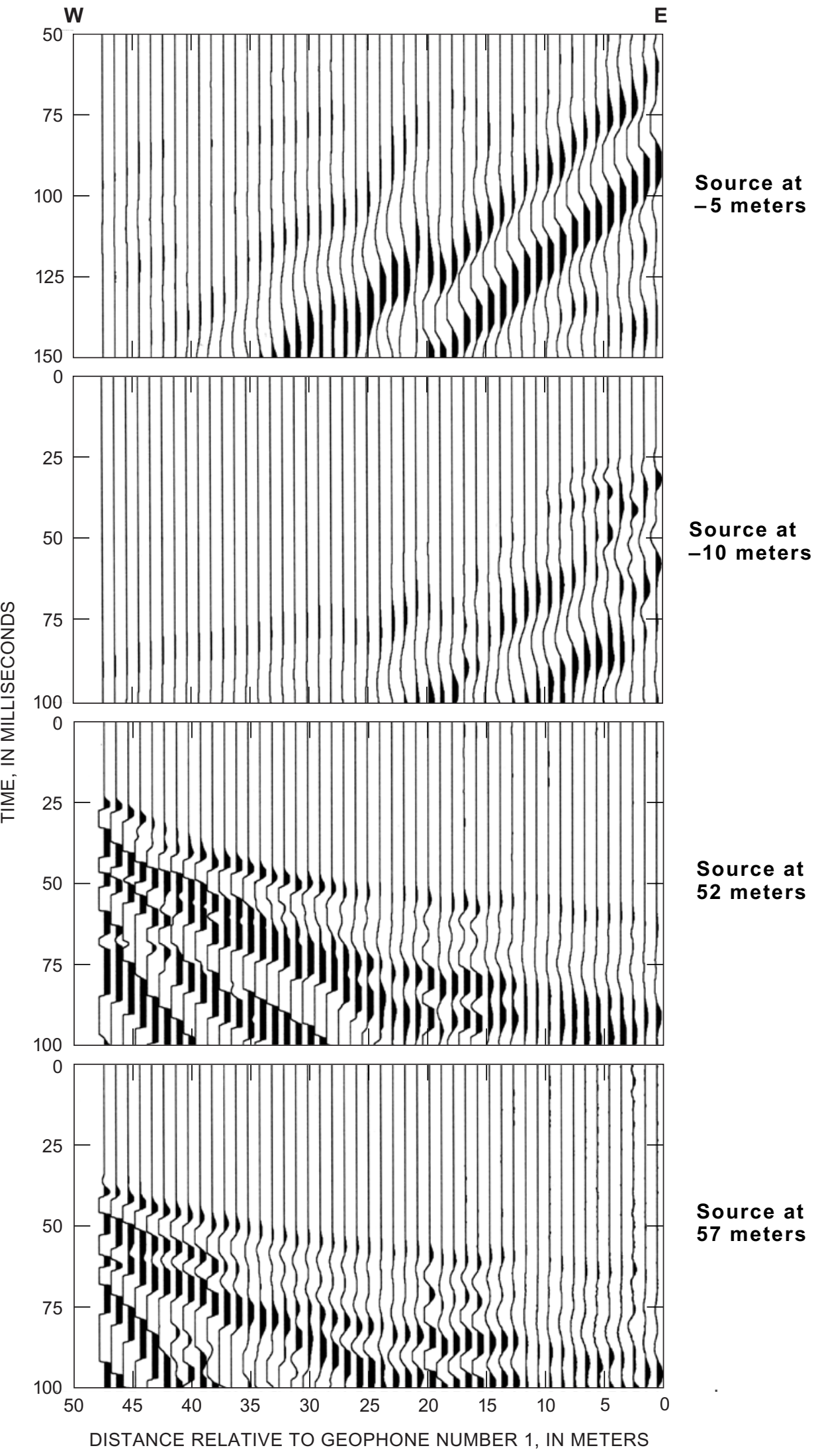

Figure 9. Seismic-refraction record from line 2 indicating low signal-to-noise ratio, making useful interpretation impossible, Pipe Spring National Monument, northern Arizona. 


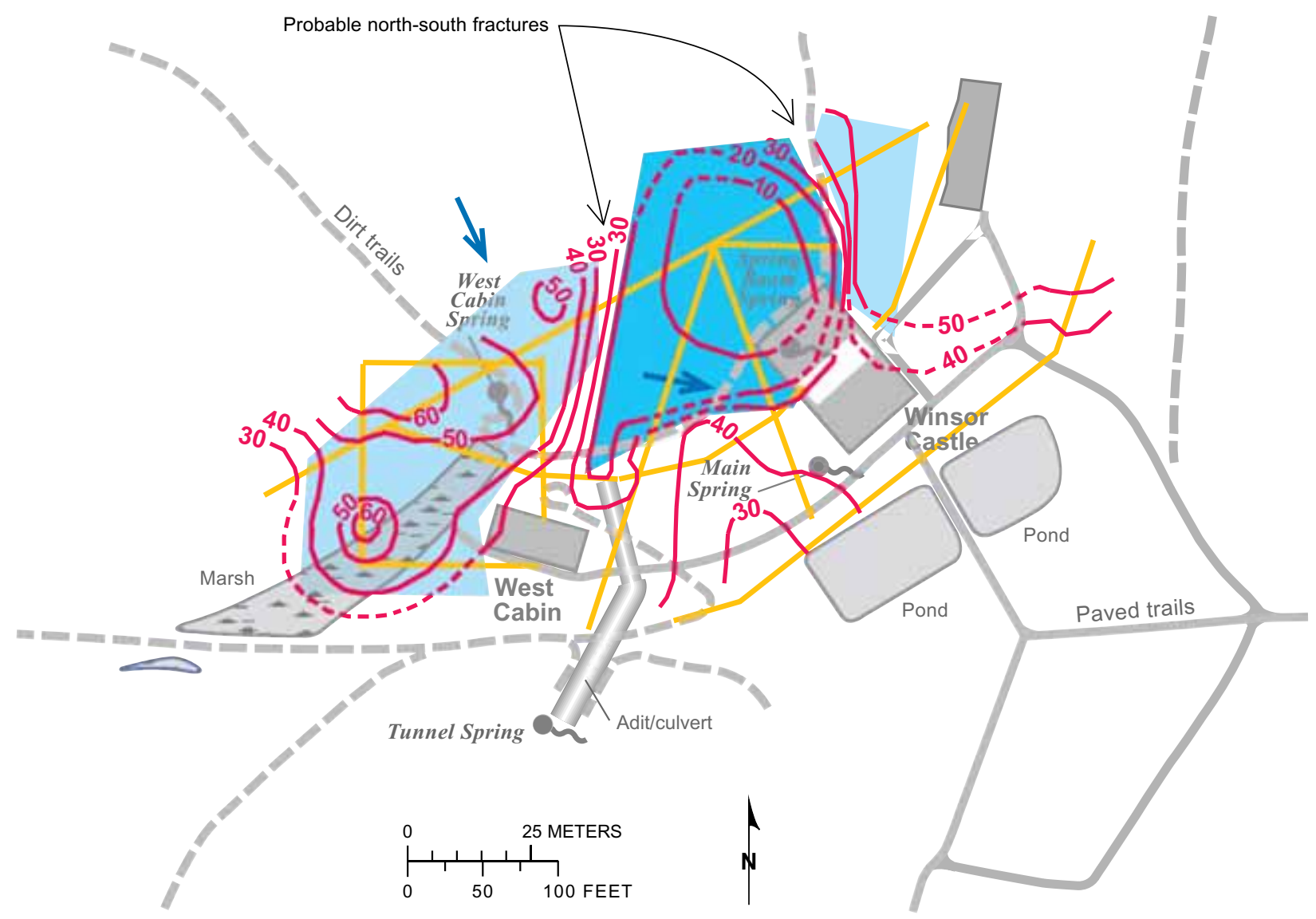

\section{EXPLANATION}

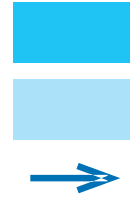

AREA OF LOW APPARENT CONDUCTIVITY

AREA OF HIGH APPARENT CONDUCTIVITY

DIRECTION OF GROUND-WATER MOVEMENT

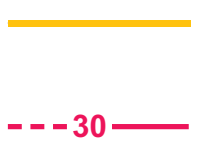

ELECTROMAGNETIC-INDUCTION (EM) LINE (EM31)

LINE OF EQUAL AVERAGE MEASURED CONDUCTIVITY - Interval 10, in millisiemens per meter. Data from EM31 measurements. Dashed where uncertain

HISTORIC STRUCTURE

Figure 10. Areas of high and low apparent conductivity, Pipe Spring National Monument, northern Arizona. 
A. LINE 402 (see figure 3 for location)

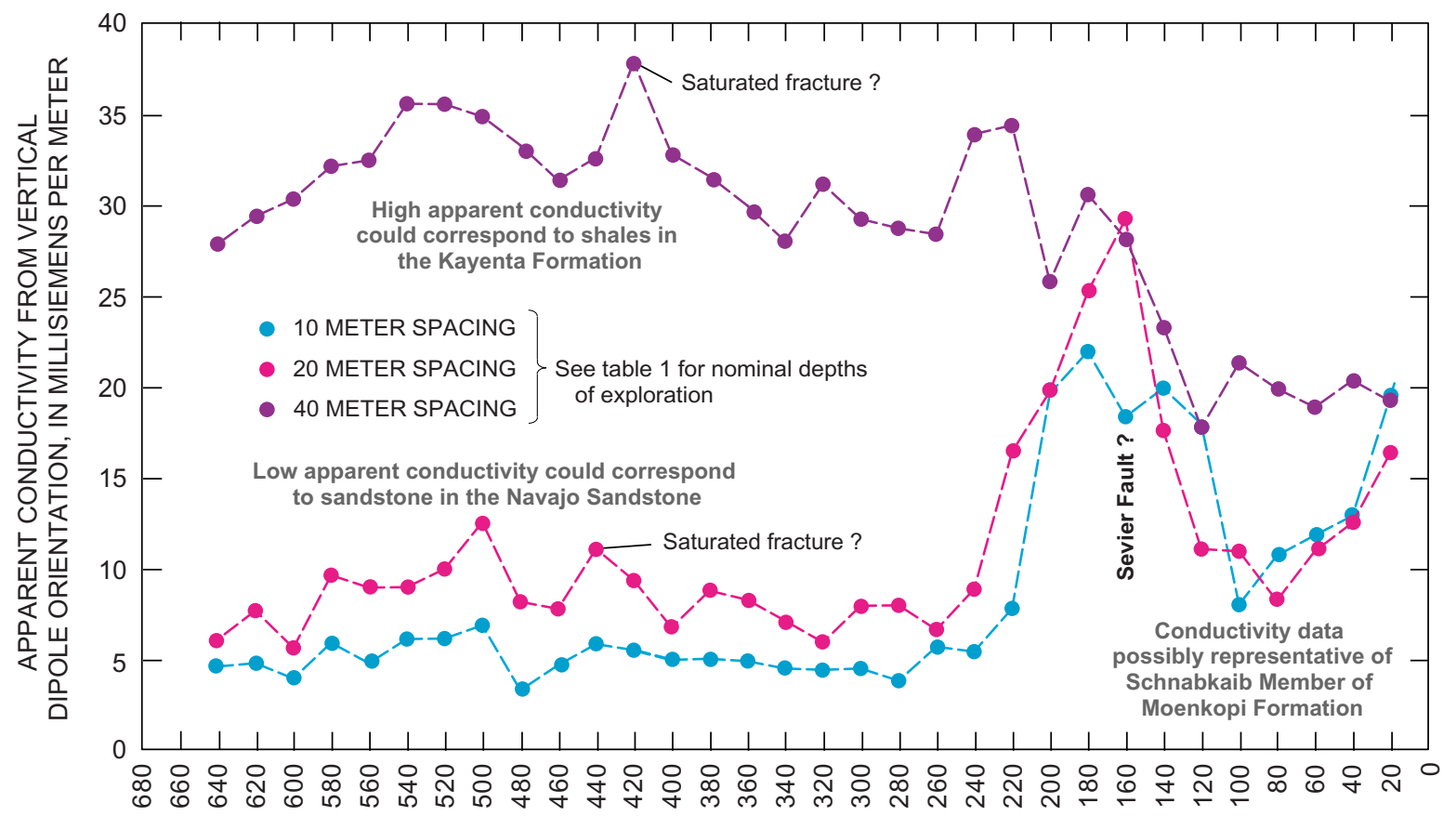

DISTANCE, IN METERS FROM EAST END

B. LINE 401 (see figure 3 for location)

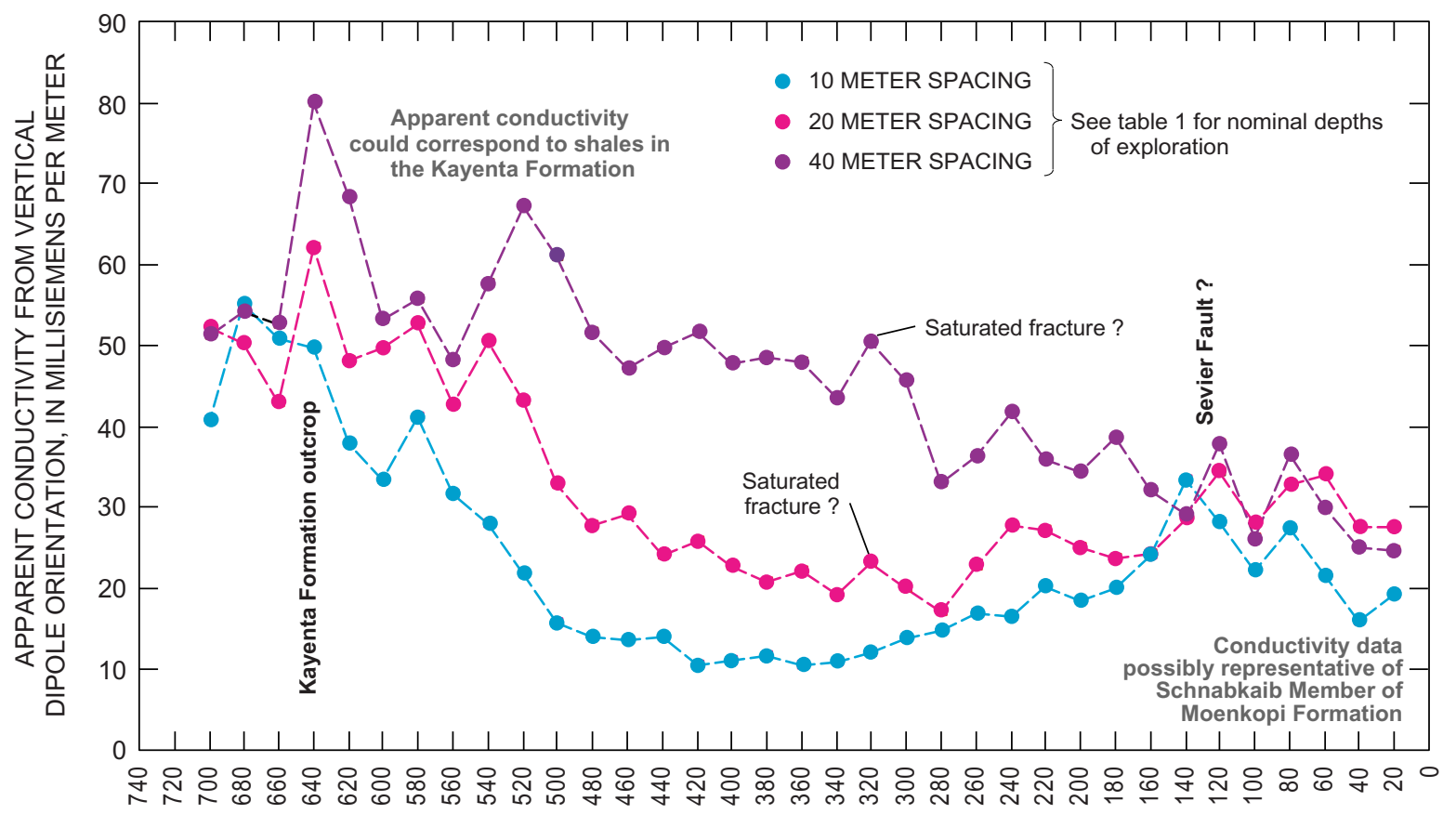

DISTANCE, IN METERS FROM EAST END

Figure 11. Apparent conductivity from EM34 data north of Pipe Spring National Monument, northern Arizona. 
This greater difference can probably be attributed to the thick sequence of the Schnabkaib Member underlying the eastern part of the line and distinct lithologic differences between the Navajo Sandstone and the Kayenta Formation that underlie the western part of the line.

From east to west along EM34 line 401 (fig. 11B), the change from the Schnabkaib Member of the Moenkopi Formation to the shaly sediments of the Kayenta Formation along the trace of the Sevier Fault is intimated at about 120 to $140 \mathrm{~m}$ (fig. 11B). The more consistent values of apparent conductivity from the three spacings on line 401 compared to those from line 402 are likely due to the position of subsurface units associated with the syncline (fig. 3). The Navajo Sandstone may be present for only a few meters west of the Sevier Fault, and the fine-grained sediments of the Kayenta Formation that would have an apparent conductivity similar to that of the fine-grained sediments of the Schnabkaib Member of the Moenkopi Formation are likely the predominate subsurface strata in this area. Increases in apparent conductivity beginning at about $640 \mathrm{~m}$ probably correlate to an outcrop of the fine-grained facies of the Kayenta Formation that extends more than $100 \mathrm{~m}$ below the land surface (George Billingsley, geologist, U.S. Geological Survey, oral commun., 2004).

Spikes in apparent conductivity along lines 401 and 402 may be indicative of small saturated fractures that control ground-water movement immediately north of the monument boundary (figs. 3 and 11). For example, the spike at about 420 to $460 \mathrm{~m}$ along line 402 could be indicative of a saturated fracture in the bedrock. The approximate location of the spike coincides with a small surface drainage (fig. 3) where water could be infiltrating. Along line 401, the spike in apparent conductivity at about $320 \mathrm{~m}$ for spacings of 20 and $40 \mathrm{~m}$ could be indicative of a saturated fracture in this location (fig. 11B). The spikes emphasized could represent two of many possible small fractures that are conduits for ground-water movement north of the monument.

\section{SUMMARY AND CONCLUSIONS}

Exploratory geophysical methods were employed to better understand the relation between spring discharge and geologic structure in the area of Pipe Spring National Monument. Seismic and electromagnetic-induction techniques were used in the study. The seismic-refraction technique did not yield viable results owing to the approach used. EM31 and EM34 measurements of apparent conductivity indicated that ground-water movement is partially controlled by fractures.
EM31 data indicated that saturated conditions exist near West Cabin Spring and in an area east of Winsor Castle on Winsor Point. EM34 results indicated that saturated conditions could exist within small fractures associated with monoclines and synclines and the Sevier Fault.

Data from the preliminary geophysical surveys conducted in this investigation indicate that ground-water discharge to the springs in Pipe Spring National Monument is controlled by geologic structure. Additional, more detailed study could be used to verify and expand on these limited conclusions. Future studies that include direct resistivity methods to map the twodimensional distribution of electrical properties within the monument could better delineate faults and fractures, and the relations of these structures to ground-water movement and spring discharge.

\section{SELECTED REFERENCES}

Barrett, D.C., and Williams, O.R., 1986, An evaluation of the decline in spring flow at Pipe Spring National Monument: Fort Collins, Colorado, National Park Service report, 13 p.

Bassler, Harvey, and Reeside, J.B., Jr., 1921, Oil prospects in Washington County, Utah: U.S. Geological Survey Bulletin, 0726-C, p. 87-107.

Fetter, C.W., 1994, Applied Hydrology, 3d ed.: Englewood Cliffs, New Jersey, Prentice-Hall, p. 557

Harshbarger, J.W., Repenning, C.A., and Irwin, J.H., 1957, Stratigraphy of the uppermost Triassic and the Jurassic rocks of the Navajo country: U.S. Geological Survey Professional Paper 291, 74 p.

Inglis, Rick, 1997, Monitoring and analysis of spring flows at Pipe Spring National Monument, Mojave County, Arizona: Fort Collins, Colorado, National Park Service Water Resources Division Technical Report NPS/NRWRD/NRTR-97125, $35 \mathrm{p}$.

Marshall, C.H., 1956, Photogeologic map of the Fredonia, SW Quadrangle, Mohave County, Arizona: U.S. Geological Survey Miscellaneous Investigations Series, Map I-160, scale $1: 24,000$.

Northwest Geophysical Associates, Inc., 2000, Electromagnetic Induction, accessed January 29, 2004, at URL http://www.nga.com/pdf_folder/EM_flyer.pdf.

U.S. Public Health Service, 1962, Drinking water standards: U.S. Public Health Service Publication 956, 61 p.

Truini, Margot, 1998, Geohydrology of Pipe Spring National Monument area, Northern Arizona: U.S. Geological Survey Water-Resources Investigations Report 98-4263, 25 p. 
This page left blank intentionally. 
This page left blank intentionally. 

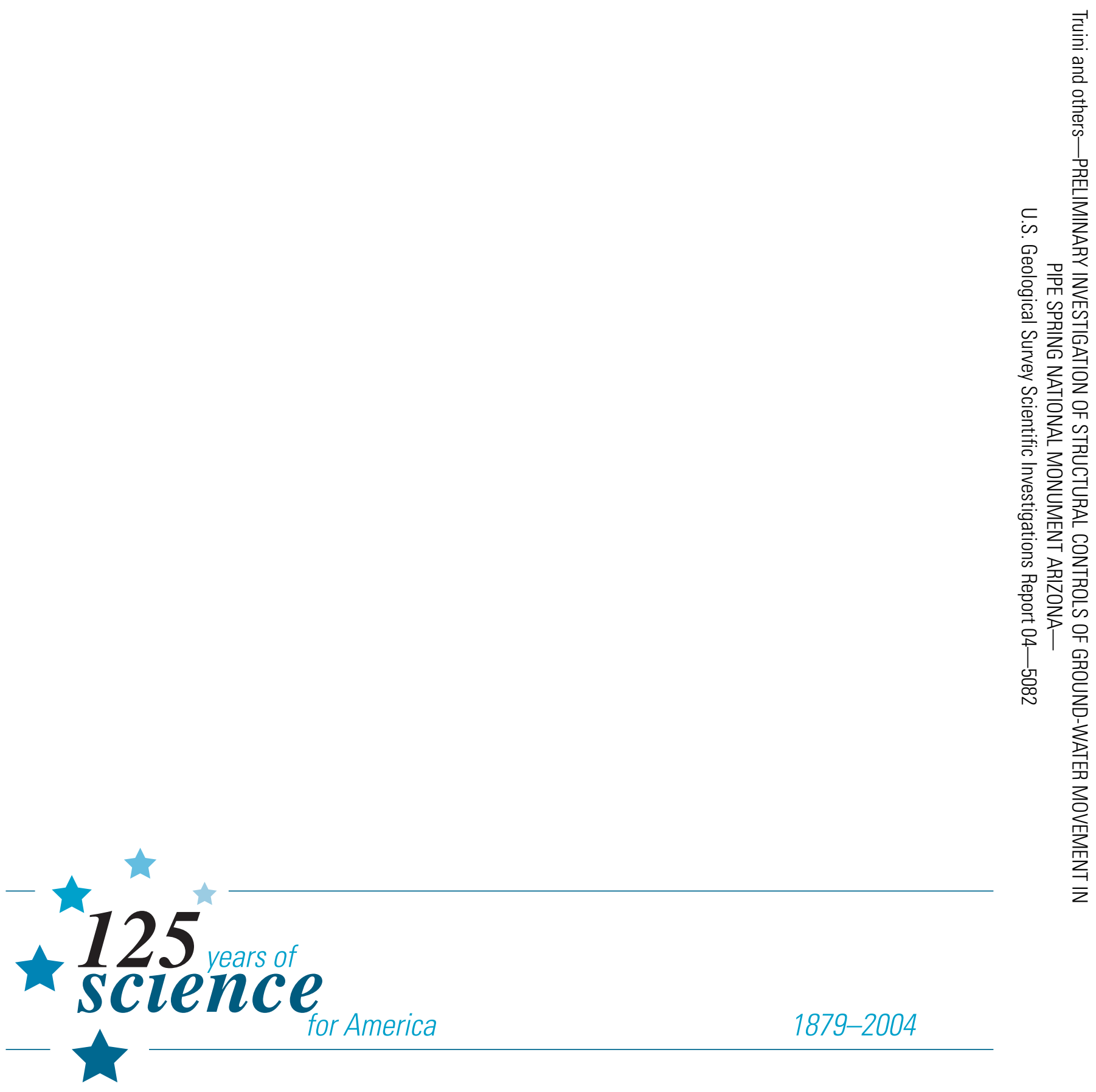

๑) Printed on recycled paper 